\title{
Seed germination of Bowdichia virgilioides Kunth, under water stress
}

Lígia M. de M. Silva ${ }^{1}$, Ivor B. de Aguiar $^{2}$ \& Teresinha de J.D. Rodrigues ${ }^{3}$

\author{
${ }^{1}$ FCAV/UNESP. Via de Acesso Prof. Paulo Donato Castellane, CEP 14870-000, Jaboticabal, SP. E-mail: ligia@asbyte.com.br (Foto) \\ ${ }^{2}$ FCAV/UNESP, Departamento de Produção Vegetal. E-mail: ivor@netsite.com.br \\ ${ }^{3}$ FCAV/UNESP, Departamento de Biologia Aplicada à Agropecuária. E-mail: tedelro@fcav.unesp.br
}

Protocolo $065-13 / 06 / 2000$

\begin{abstract}
Bowdichia virgilioides (Leguminosae-Papilionoideae) is a native tree species in Brazil characteristic of the savannah vegetation. Seeds of this species were submitted to different osmotic potentials induced by polyethyleneglycol (PEG-6000) in order to verify their resistance to drought conditions. Seeds were previously scarified with sulphuric acid and incubated at $25{ }^{\circ} \mathrm{C}$ with an eight hours photoperiod, at osmotic potentials of $0.0,-0.1,-0.3,-0.5,-0.7,-0.9$ and $-1.1 \mathrm{MPa}$. It was found that water stress resistance limit ranged from -0.7 to $-0.9 \mathrm{MPa}$. Significant reduction in germination velocity from $-0.3 \mathrm{MPa}$, and final percentage of germination from -0.5 MPa in relation to control, were observed. Germination under drastic conditions of water stress was inhibited, but was restored with an increase of water availability.
\end{abstract}

Key words: forest seed, physiological quality, osmotic potential, polyethyleneglycol

\section{Germinação de sementes de Bowdichia virgilioides Kunth, sob estresse hídrico}

\begin{abstract}
Resumo: Bowdichia virgilioides (Leguminosae-Papilionoideae) é uma espécie arbórea nativa do Brasil, característica da vegetação de cerrado, denominada principalmente de sucupira-preta. Sementes dessa espécie foram escarificadas com ácido sulfúrico e submetidas a diferentes potenciais osmóticos, induzidos por polietilenoglicol (PEG-6000), com o objetivo de avaliar a sua resistência a condições de seca. As sementes foram colocadas para germinar a $25{ }^{\circ} \mathrm{C}$, sob fotoperíodo de oito horas, nos potenciais osmóticos de $0,0,-0,1,-0,3,-0,5,-0,7,-0,9$, e -1,1 MPa. Pelos resultados obtidos, observou-se que o limite de resistência da espécie ao estresse hídrico situa-se entre $-0,7$ e $-0,9 \mathrm{MPa}$. A velocidade de germinação foi significativamente reduzida a partir de $-0,3 \mathrm{MPa}$ e a porcentagem final a partir de $-0,5 \mathrm{MPa}$, em relação às sementes não submetidas ao estresse hídrico. Sob drásticas condições de estresse hídrico não houve germinação das sementes, que foi restabelecida com o aumento da disponibilidade de água.
\end{abstract}

Palavras-chave: semente florestal, qualidade fisiológica, potencial osmótico, polietilenoglicol

\section{INTRODUCTION}

Although germination pattern is governed by the genetic constitution of the species, its expression is frequently modified by environmental conditions in which the seeds are produced (Santos et al.,1992). Water availability is one of the environmental factors that influences most the germinative process, a water deficiency limiting the plants survival and early growth (Blake,1993)

Water is the initiatory factor of germination, and is directly or indirectly involved in all the other steps of the subsequent metabolism. Its participation is decisive in the enzymatic reactions, in the solubilization and transportation of metabolites, as well as a reagent in the hydrolytic digestion of proteins, carbohydrates and lipids in the storage tissues of the seed (Mayer \& Poljakoff-Mayber, 1989; Carvalho \& Nakagawa, 2000).
In order to occur imbibition, the water potential of seeds must be lower than that of the environment, for water to move to their interiors (Borges \& Rena, 1993). Very low water potential especially in the beginning of imbibition, prevents water uptake by the seed, and might make unviable the events sequence which culminate with the seedlings emergence (Bansal et al., 1980). Water stress may affect seed germination, delaying its beginning or decreasing the final germinability (Hardegree \& Ermmerich, 1990)

Osmotic agents as mannitol and polyethyleneglycol have been used in germination studies, to simulate low moisture conditions of soil (Perez, 1995). Polyethyleneglycol has been more effective, in research works, as it does not penetrate in the cells, is not degraded and does not cause toxicity, due to its high molecular weight (Hasegawa et al., 1984) 
According to Hadas (1976), the critical soil water potential, for seed germination, is typical for each species. Therefore, solutions with different osmotic potentials have been used, on different species, in order to establish seed resistance to water stress. Very low water potential may act as germinative pretreatment to increase and to accelerate seed germination (Borges et al., 1991) and induce seeds to secondary dormancy (Cavalcante \& Perez, 1995). Low water potentials, as well as high temperatures and abscisic acid, cause blockage between the quiescent seed stage and the germination phase and can not be considered as factors which induce dormancy but as factors that inhibit germination (Khan \& Andreoli, 1993; Khan, 1994). Conditioning in suitable osmotic potential may also favor the conservation of seeds stored under uncontrolled environment conditions (Barbedo et al., 1997).

Researches with Brazilian forest species, to define seed resistance to water stress, are recent. Studies were conducted with Dalbergia nigra, Cedrela fissilis (Borges et al., 1991), Esenbeckia leiocarpa (Córdoba et al., 1995), Pterogyne nitens (Nassif \& Perez, 1997), Stryphnodendron polyphyllum (Tambelini \& Perez, 1998) and Peltophorum dubium (Perez et al., 1998).

Bowdichia virgilioides (Leguminosae-Papilioideae) is a tree characteristic of the Brazilian savannah, adapted to drought and poor lands, known mainly as "sucupira-preta" (Lorenzi, 1992). It has apicultural properties (Brandão \& Ferreira, 1991), its wood can be used for several purposes and the plant is recommended to landscape and restoring degraded areas (Lorenzi, 1992).

In this study, seeds of B. virgilioides were submitted to different osmotic potentials obtained with polyethyleneglycol, simulating drought conditions, in order to evaluate the resistance of seeds to water stress.

\section{MATERIAL AND METHODS}

Seeds used in this experiment were extracted from mature fruits harvested in November1999 in the Cuiabá-MT region, in a savannah area. Following harvest, fruits were sun dried to make easy their manual opening and release of seeds, as recommended by Lorenzi (1992). The seeds were sent to the Departament of Plant Production of the Universidade Estadual Paulista, in Jaboticabal-SP, being stored in a cold and dry chamber $\left(10^{\circ} \mathrm{C}\right.$ and $60 \%$ relative humidity $)$ during 40 days.

Before the experiment, seeds were manually selected in order to constitute an uniform lot in relation to size and external characteristics. After that, seeds were scarified with concentrated sulphuric acid (95-98\%) during five minutes (Silva et al., 1994a), and washed first in tap water and after in distilled water. Subsequently, seeds were immersed in a $4 \%$ sodium hypochlorite solution during $10 \mathrm{~min}$ and dried in paper-towels.

To simulate water stress, polyethyleneglycol solutions (PEG6000 ) equivalent to the following osmotic potentials, prepared according to Michel \& Kaufmann (1973), were used: 0.0, -0.1, $-0.3,-0.5,-0.9$ and $-1.1 \mathrm{MPa}$. Filter paper sheets previously autoclaved and moistened with $20 \mathrm{~mL}$ of test solution plus $0.2 \%$ nystatin were used as a substrate (Santos \& Pereira, 1987).

Germination tests were conducted at $25^{\circ} \mathrm{C}$, with an eight hours photoperiod (Silva et al., 1994b). Seeds were distributed over the substrate, in gerbox sealed with PVC film to avoid evaporation.
Seeds which presented primary roots at least one $\mathrm{cm}$ long were considered germinated. Countings were done daily and tests were finished when the germination stabilized. Final percentage, average time and germination speed of the seeds were calculated according to the formulae described by Labouriau \& Valadares (1976).

A completely randomized design was adopted for the experiment, with four replications of 25 seeds. Data of both germination percentage and speed were submitted to variance and regression analysis. Percentage data were transformed in $\operatorname{arc} \sin \sqrt{\%}$ for variance analysis and the means were compared by the Tukey test at $5 \%$ probability.

Seeds which were not germinated at the end of the germination test period were washed with distilled water and transferred to gerbox lined with filter paper moistened with 10 $\mathrm{mL}$ of $0.2 \%$ nystatin solution. After that, seeds were incubated under the previously described conditions, in order to verify viability and recovery of seed germination. Soft and yellow seeds were considered dead

\section{RESULTS AND DISCUSSION}

Germination percentage and speed of Bowdichia virgilioides seeds decreased as the osmotic potential of the germinative medium decreased (Table 1). Germination was completely inhibited at $-0.9 \mathrm{MPa}$, indicating that the species resistance limit to the water stress is between - 0.7 and $-0.9 \mathrm{MPa}$. The linear decrease of both parameters is shown in Figures 1 and 2 obtained from the regression analysis.

Table 1. Percentage, average time (ATG) and speed of germination (SG) of Bowdichia virgilioides seeds submitted to different osmotic potentials

\begin{tabular}{|c|c|c|c|c|}
\hline \multirow{2}{*}{$\begin{array}{l}\text { Osmotic Potential } \\
\text { (MPa) }\end{array}$} & \multicolumn{2}{|c|}{ Germination } & \multirow{2}{*}{$\begin{array}{l}\text { ATG } \\
\text { (day) }\end{array}$} & \multirow{2}{*}{$\frac{\mathrm{SG}}{\left(\mathrm{day}^{-1}\right)}$} \\
\hline & $(\%)$ & $(\operatorname{arc} \sqrt{\%} \sin )$ & & \\
\hline 0.0 & 91.0 & $73.4 \mathrm{a}$ & 2.1 & $0.56 \mathrm{a}$ \\
\hline-0.1 & 88.0 & $70.2 \mathrm{a}$ & 2.5 & $0.36 \mathrm{ab}$ \\
\hline-0.3 & 72.0 & $59.1 \mathrm{a}$ & 4.9 & $0.21 \mathrm{bc}$ \\
\hline-0.5 & 29.0 & $32.2 \mathrm{~b}$ & 11.8 & $0.09 \mathrm{c}$ \\
\hline-0.7 & 10.7 & $15.5 \mathrm{~b}$ & 14.2 & $0.06 \mathrm{c}$ \\
\hline-0.9 & 0.0 & - & - & - \\
\hline-1.1 & 0.0 & - & - & - \\
\hline CV (\%) & & 15.7 & & 22.9 \\
\hline
\end{tabular}

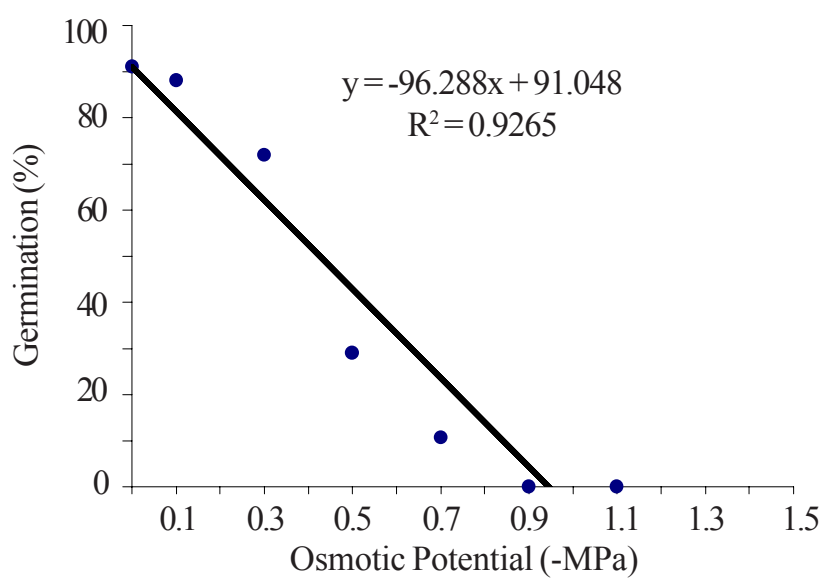

Figure1. Germination percentage of Bowdichia virgilioides seeds under different osmotic potentials 


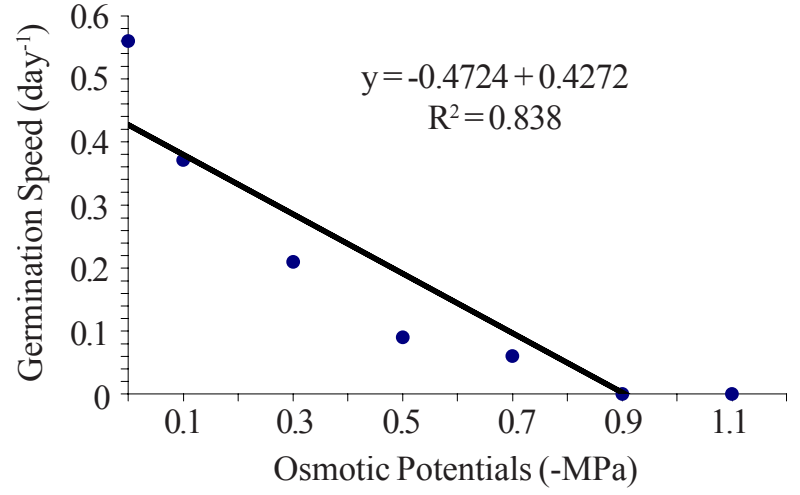

Figure 2. Germination speed of Bowdichia virgiliodes seeds under different osmotic potentials

Maximum values of germination in the presence of the osmotic agent were observed in potentials of $-0.1 \mathrm{MPa}$ and $-0.3 \mathrm{MPa}$, and did not differ as compared to control (Table 1). Osmotic potentials, from $-0.1 \mathrm{MPa}$, have acted progressively as a germination inhibitor factor, leading to lower germinability than the control. The average time of germination increased as the osmotic potential decreased, being 2.1 days for seeds under control and 14.2 days for seeds submitted to osmotic potential of - $0.7 \mathrm{MPa}$.

Emergence inhibition of the primary root, with lower water availability, is related to the reduction of enzymatic activity and, subsequently, with the decrease of the seed metabolism, necessary for digestion of reserve substances and translocation of metabolized products (Bewley \& Black, 1994).

Percentage and speed of germination decreased with the increase of water stress, simulated by PEG-6000, was observed for all Brazilian tree species previously studied. The resistance limit for Bowdichia virgilioides is higher in comparison to that verified for Cedrela fissilis (between -0.2 and $-0.4 \mathrm{Mpa}$ ) by Borges et al. (1991), and similar to the ones observed (between -0.6 and -0.9 Mpa) for Dalbergia nigra (Borges et al., 1991), Esenbeckia leiocarpa (Córdoba et al., 1995) and Stryphnodendron polyphyllum (Tambelini \& Perez, 1998), and lower to the one observed for Pterogyne nitens (Nassif \& Perez, 1997), between -1.0 and -1.2 MPa, and Peltophorum dubium (Perez et al., 1998), between -1.2 and -1.4 MPa. Seeds which are more resistant to water stress have an ecological advantage to establish seedlings in areas where more sensitive seeds can not germinate (Bewley \& Black, 1994).

There was a significant decrease in the germination percentage of Bowdichia virgilioides seeds from - $0.5 \mathrm{MPa}$ in relation to the control (Table 1). Germination speed was more sensitive than the germination percentage, starting to differ significantly from the control at $-0.3 \mathrm{MPa}$. At this potential, the average time of germination was five days, two and half times longer than the seeds not submitted to water stress. Germination speed was also a more sensitive parameter to water stress compared to germination percentage, as Nassif \& Perez (1997) have observed for Pterogyne nitens, Tambelini \& Perez (1998) for Stryhnodendron polyphyllum and Perez et al. (1998) for Peltophorum dubium seeds.

The germination capacity of non germinate Bowdichia virgilioides seeds belonging to PEG 6000 solutions with osmotic potential from - $0.5 \mathrm{MPa}$, was recovered after the seeds were washed and placed to germinate in a nystatin solution (Table 2). Germination was found to be more than $80 \%$, even in the potentials in which germinability was null in the previous test, although they presented 15 to $18 \%$ of dead seeds, probably due to interaction between germination delay, caused by low osmotic potential, and fungi infection.

Table 2. Germinated and dead seeds of Bowdichia virgilioides under favorable moisture conditions after being submitted to different osmotic potentials

\begin{tabular}{ccc}
$\begin{array}{c}\text { Osmotic Potential } \\
(\mathrm{MPa})\end{array}$ & $\begin{array}{c}\text { Germinated Seeds } \\
(\%)\end{array}$ & Dead Seeds (\%) \\
\hline-0.5 & 94.4 & 4 \\
-0.7 & 96.6 & 3 \\
-0.9 & 85.0 & 15 \\
-1.1 & 82.0 & 18 \\
\hline
\end{tabular}

For Peltophorum dubium seeds, Perez et al. (1998) have also verified germinability recovery when seeds previously submitted to solutions with very low values of osmotic potential were washed and placed to germinate in a substrate moistened with distilled water. Germination failure under water stress may be considered as secondary or induced dormancy, which in many species is readily reversible when water availability is increased (Hegarty, 1978). However, other authors consider that water stress is a factor which inhibits germination but it is not a dormancy induction factor (Khan \& Andreoli, 1993; Khan, 1994).

Secondary dormancy may be induced in mature seeds, already dispersed, in response to the unfavorable environmental conditions. Induction mechanism is unknown, but it is known that metabolic changes constitute a survival strategy of the species. As seeds are heterogeneous in their response to water stress, in natural conditions, germination is distributed in time and space, increasing the probability of the seedlings to find suitable conditions for establishment and development (Bewley \& Black, 1994).

\section{CONCLUSIONS}

1. Resistance limit for germination of Bowdichia. virgilioides seeds under water stress conditions, is between -0.7 and $-0.9 \mathrm{MPa}$.

2. Germination speed is more sensitive to water stress conditions than percentage of germination.

3. Drastic conditions of water stress hindered seed germination, but seeds recovered germination capacity with the increase of water availability.

\section{LITERATURE CITED}

Bansal, R.P.; Bhati, P.R.; Sen, D.N. Differential specificity in water inhibition of Indian arid zone. Biologia Plantarum, Copenhagne, v.22, p.327-331, 1980.

Barbedo, C.J.; Marcos Filho, J.; Novembre, A.D.L.C. Condicionamento osmótico e armazenamento de sementes de cedro-rosa (Cedrela fissilis Vell.). Revista Brasileira de Sementes, Brasília, v.19, n.2, p.355-361, 1997. 
Bewley, J.D.; Black, M. Seeds: Physiology of development and germination. 2.ed. New York: Plenum Press, 1994. 445p.

Blake, T.J. Transplanting shock in white spruce: Effect of cold storage and root pruning on water relations and stomatal conditioning. Plant Physiology, Rockville, n.57, p.210-216, 1993.

Borges, E.E.L.; Rena, A.B. Germinação de sementes. In: Aguiar, I.B.; Piña-Rodrigues, F.C.M.; Figliolia, M.B. Sementes florestais tropicais. Brasília: ABRATES, 1993. p.83-135.

Borges, E.E.L.; Vasconcelos, P.C.S.; Carvalho, D.V.; Borges, R.C.G. Estudos preliminares sobre o efeito do estresse hídrico na germinação de sementes de jacarandá-da-Bahia (Dalbergia nigra) e cedro-rosa (Cedrela fissilis). Revista Brasileira de Sementes, Brasília, v.13, n.2, p.115-118, 1991.

Brandão, M.; Ferreira, P.B.D. Flora apícola do cerrado. Informe Agropecuário, Belo Horizonte, v.15, n.168, p.4-8, 1991.

Carvalho, N.M.; Nakagawa, J. Germinação de sementes. In: Carvalho, N.M.; Nakagawa, J. Sementes: Ciência, tecnologia e produção. 4.ed. Jaboticabal: FUNEP, 2000. p.128-166.

Cavalcante, A.M.B.; Perez, S.C.J.G.A. Efeitos dos estresses hídrico e salino sobre a germinação de sementes de Leucaena leucocephala (Lam.) de Wit. Pesquisa Agropecuária Brasileira, Brasília, v.30, n.2, p.281-289, 1995.

Córdoba, G.A.T.; Borges, E.E.L.; Borges, R.C.G.; Neves, J.C.L. Osmocondicionamento em sementes de Esenbeckia leiocarpa Engl (guarantã). Revista Brasileira de Sementes, Brasília, v.17, n.2, p.217-226, 1995.

Hadas, A. Water uptake and germination of leguminous seeds under changing external water potential in osmotic solutions. Journal of Experimental Botany, Oxford, v.27, n.98, p.480489, 1976.

Hardegree, S.P.; Emmerich, W.E. Effect of polyethylene glycol exclusion on the water potential of solution saturated filter paper. Plant Physiology, Rockville,v.92, p.462-466, 1990.

Hasegawa, P.M.; Bressan, R.A.; Handa, S.; Handa, A.K. Cellular mechanisms of tolerance to water stress. Hortscience, Alexandria, v.19, n.3, p.371-377, 1984.

Hegarty, T.W. The physiology of seed hydratation and dehydratation, and the relation between water stress and the control of germination: A review. Plant Cell and Environment, New York, v.1, p.101-119, 1978.

Khan, A.A. Introduction of dormancy in nondormant seeds. Journal of American Society of Horticultural Science, Alexandria, v.119, n.3, p.408-413, 1994.

Khan, A.A.; Andreoli, C. Hormonal control of seed dormancy and germination under stressful and nonstressful conditions. In: International Workshop on Seeds, 4, 1993. Proceedings... Paris. ASFIS.1993, v.2, p.630-635.
Labouriau, L.G.; Valadares, M.E.B. On the germination of seeds of Calotropis procera (Ait.) Ait. f. Anais da Academia Brasileira de Ciências, Caracas, v.48, n.2, p.236-284, 1976.

Lorenzi, H. Bowdichia virgilioides Kunth. In: Lorenzi, H. Árvores brasileiras: Manual de identificação e cultivo de plantas arbóreas nativas do Brasil. Nova Odessa: Editora Plantarum, 1992. p.195.

Mayer, A.M.; Poljakoff-Mayber, A. The germination of seeds. 4.ed. New York: Pergamon Press, 1989. 270p.

Michel, B.E.; Kaufmann, M.R. The osmotic potential of polyethylene glicol 6000. Plant Physiology, Rockville, v.51, p.914-916, 1973.

Nassif, S.M.L.; Perez, S.C.J.G.A. Germinação de sementes de amendoim-do-campo (Pterogyne nitens Tul. - FabaceaeCaesalpinoideae) submetidas a diferentes condições de estresse hídrico e salino. Revista Brasileira de Sementes, Brasília, v.19, n.2, p.143-150, 1997.

Perez, S.C.J.G.A. Ecofisiologia de sementes florestais. Informativo ABRATES, Londrina, v.5, n.3, p.13-30, 1995.

Perez, S.C.J.G.A.; Fanti, S.C.; CASALI, C.A. Influência da temperatura sobre a resistência das sementes de canafístula (Peltophorum dubium (Spreng) Taubert) ao estresse hídrico simulado. Revista Brasileira de Sementes, Brasília, v.20, n.2, p.334-341, 1998.

Santos, D.S.B.; Pereira, M.F. Germinação de sementes de dois cultivares de beterraba açucareira: Efeito de luz e temperatura. Revista Brasileira de Botânica. v.10, p.15-20. 1987.

Santos, V.L.M.; Calil, A.C.; Ruiz, H.A.; Alvarenga, E.M.; Santos, C.M. Efeito do estresse salino e hídrico na germinação e vigor de sementes de soja. Revista Brasileira de Sementes, Brasília, v.14, n.2, p.189-194, 1992.

Silva, L.M.M.; Matos, V.P.; Lima, A.A. Ecofisiologia e morfologia da germinação de sementes de sucupira (Bowdichia virgilioides Kunth.). In: Congresso Nacional de Pós-Graduandos, 9, e Congresso Científico de Pós-Graduandos, 1, 1994, São Carlos. Anais... São Carlos: Universidade Federal de São Carlos, 1994a. p.122-123.

Silva, L.M.M.; Matos, V.P.; Lima, A.A. Tratamentos prégerminativos em sementes de sucupira (Bowdichia virgilioides Kunth.). In: Reunião Nordestina de Botânica, 18, 1994, Areia. Resumos... Areia: Universidade Federal da Paraíba, 1994b. p.148.

Tambelini, M.; Perez, S.C.J.G.A. Efeitos do estresse hídrico simulado com PEG(6000) ou manitol na germinação de sementes de barbatimão (Stryphnodendron polyphyllum Mart.). Revista Brasileira de Sementes, Brasília, v.20, n.1, p.226-232, 1998. 